\title{
Pendampingan Penyusunan Pembukuan Sederhana \\ Pada KUB "Forum Pemberdayaan Wanita Mandiri" \\ Di Desa Tanggung Kecamatan Padang \\ Kabupaten Lumajang
}

\author{
Ninik Lukiana \\ Program Studi Manajemen, STIE Widya Gama Lumajang \\ ibundaninik@gmail.com
}

\begin{abstract}
Abstrak
Kelompok Usaha Bersama "Forum Pemberdayaan Wanita Mandiri” merupakan industri kecil makanan dan minuman olahan serta aneka kue kering dari bahan baku yang mudah didapatkan di Desa Tanggung. Industri ini adalah merupakan kumpulan ibu rumah tangga yang keratif dan semangat untuk tetap bertahan memproduksi suatu makanan, minuman olahan dan kue kering dan mengalami kemajuan dalam menghadapi persaingan yang semakin banyak dan ketat, sehingg ke depannya menjadi wanita mandiri untuk membantu income keluarganya. Kegiatan pengabdian masyarakat ini adalah untuk menggali potensi pengembangan usaha makanan minuman serta kue kering mempunyai ciri khas desa Tanggung Kecamatan Padang Kabupaten Lumajang, dengan rencana kegiatan berupa: pelatihan dan pendampingan pengelolaan keuangan berupa pencatatan pembukuan sederhana, memberi bantuan buku catatan transaksi keuangan sederhana, serta alat proses produksi cake/roti dan kue kering berupa alat pengaduk atau pencampur bahan kue dan alat untuk melumatkan, mencincang halus, dan kasar makanan, sayuran dan buah-buahan. Luaran kegiatan berupa: kemampuan membuat pembukuan sederhana, pemberian bantuan buku pembukuan dan alat pengaduk atau pencampur bahan kue. Juga dilakukan, monev dari pihak sivitas STIE Widya Gama Lumajang dalam melakukan pendampingan dan pembinaan pada kelompok secara berkelanjutan kepada mitra KUB "Forum Pemberdayaan Wanita Mandiri”.
\end{abstract}

\section{Kata Kunci: Kelompok Usaha Bersama, Wanita Mandiri, Pembukuan Sederhana, Stand Mixer, dan Blender}

\begin{abstract}
The Joint Business Group "Forum Pembdayaan Wanita Mandiri" is a small food and beverage industry and various cookies from raw materials that are easily available in Tanggung Village. This industry is a collection of housewives who are fond and spirit to survive to produce a food, processed drinks and pastries and progress in the face of increasing and more competition, so in the future become an independent woman to help her family income. This community service activity is to explore the development potential of food beverage and pastry business which has characteristic of Tanggung Village, Padang Regency of Lumajang Regency, with activity plan in the form of: training and financial management assistance in the form of simple bookkeeping, giving of simple financial transaction book, the process of producing cake / bread and pastry in the form of stirrer or cake mixer and tools to pulverize, finely chop, and roughly food, vegetables and fruits. Output activities include: the ability to make simple bookkeeping, the provision of bookkeeping aid and stirrer or cake mixer. Also conducted, the monev from the civitas STIE
\end{abstract}


Widya Gama Lumajang in conducting guidance and coaching on the group in a sustainable manner to the KUB partner "Forum Pembdayaan Wanita Mandiri".

\section{Keywords: Joint Business Group, Independent Woman, Simple Bookkeeping, Stand Mixer, and Blender}

\section{PENDAHULUAN}

Pada awalnya dari beberapa ibu rumah tangga yang iseng membuat makanan olahan dari bahan singkong/ketela pohom dan pisang, minumah jahe dan bahan dari rempah-rempah. Produk yang dihasilkan oleh ibu-ibu rumah tangga tersebut, ibu-ibu mendapatkan tambahan keuangan/pendapatan yang dapat digunakan untuk membantu memenuhi kebutuhan seharihari. Berawal dari hal itulah dan banyaknya ibu-ibu rumah tangga yang menganggur serta didukung kemudahan didapatkannya: rempah-rempah, pisang, bahan baku kue, munculah gagasan dari ibu-ibu untuk membentuk sebuah perkumpulan yang tidak hanya diisi dengan mengobrol, melainkan juga menghasilkan produk yang dapat dijual. Maka pada tahun 2009 kumpulan ibu-ibu yang produktif membentuk sebuah kelompok kecil, memproduksi suatu makanan dan minuman olahan, dan disahkan menjadi sebuah kelompok usaha bersama diberi nama KUB "Forum Pemberdayaan Wanita Mandiri", dengan tujuan dapat menjadi wanita mandiri untuk membantu meningkatkan income keluarga.

Agar usaha tetap berkelanjutan, mengembangkan usaha kelompoknya, untuk meningkatkan daya saing di pasar lokal dan di pasar regional, serta lebih bertambah terserapnya tenaga kerja dari kelompok untuk kegiatan produsi di Kelompok Usaha Bersama, masih membutuhkan pelatihan dan pendampingan manajemen (bimbingan dan pelatihan penyusunan pembukuan keuangan sederhana) dan peralatan untuk proses produksi produk roti/cake dan kue kering berupa alat pengaduk atau pencampur bahan roti/cake dan kue (stand mixer), serta alat untuk melumatkan, mencincang halus, dan kasar makanan, sayuran dan buah-buahan (blender).

Kelompok Usaha Bersama "Forum Pemberdayaan Wanita Mandiri" mempunyai permasalahan antara lain:

1. Selama usahanya berlangsung KUB pencatatan transaksinya dilakukan secara tradisional dan sangat sederhana, diharapkan pengurus dapat mengelola keuangan sederhana yang benar dan tepat, sehingga memperoleh data dan informasi yang tersusun secara sistematis atau teratur dan tertib. Pengurus dapat memperhitungkan keuntungan yang diperoleh, mengetahui berapa tambahan modal yang dicapai, dan juga dapat mengetahui bagaimana keseimbangan hak dan kewajiban yang dimiliki. Sehingga setiap keputusan yang diambil oleh pengurus dalam mengembangkan usahanya akan didasarkan pada kondisi konkret keuangan yang dilaporkan secara tepat dan lengkap bukan hanya didasarkan pada asumsi semata.

2. Salah satu alat produksi yaitu produk roti/cake dan kue kering berupa alat pengaduk atau pencampur bahan/adonan kue masih berupa hand mixer/ yaitu mixer yang masih dipegang tanpa adanya penyangga,dan kemampuan mengaduk adonan masih belum optimal baik kapasitasnya dan kualitasnya.

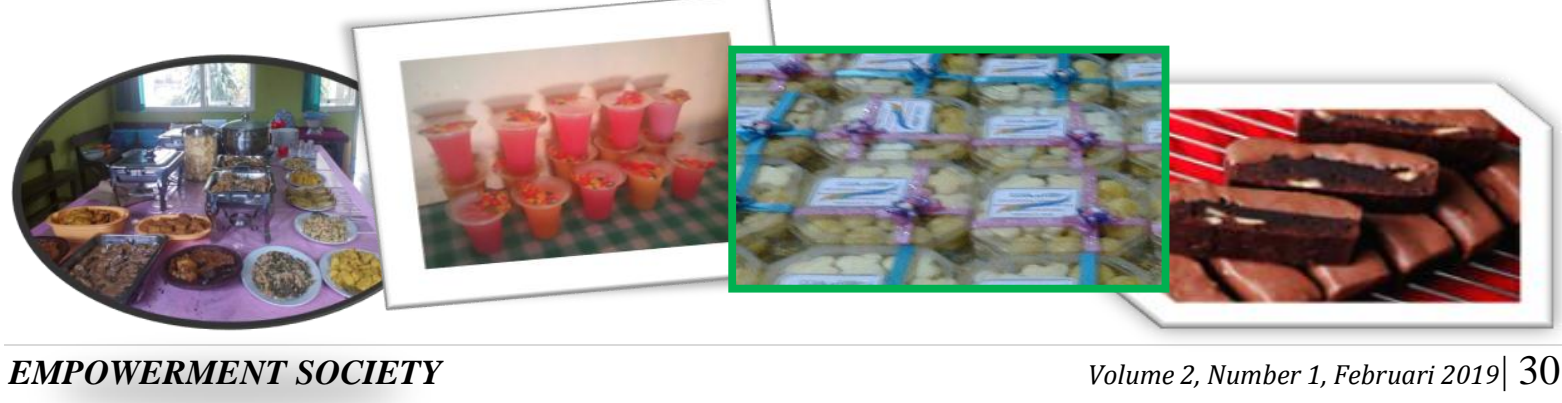




\section{Gambar 1. Usaha Catering,Minuman Olahan, Aneka Kue Kerimg dan Cake}

\section{Solusi yang Ditawarkan}

1. Memberikan pelatihan dan pendampingan pencatatan pembukuan sederhana.

2. Memberikan bantuan dana untuk pembuatan beberapa buku catatan transaksi keuangan dan laporan keuangan sederhana.

3. Memberikan bantuan dana untuk pengadaan alat pengaduk atau pencampur bahan/adonan roti/cake dan kue kering masih berupa stand mixer dan blinder.

Target luaran yang diharapkan dari kegiatan pengabdian pada masyarakat bagi usaha batik ke dua mitra antara lain:

1. Peningkatan keterampilan pengurus UKM dalam membuat pembukuan sederhana yang benar dan tepat serta berkelanjutan.

2. Mendapatkan dana untuk pembuatan beberapa buku catatan transaksi keuangan dan pemnukuan keuangan sederhana.

3. Pengembangan usaha dan peningkatan pendapatan untuk semua anggota KBU.

4. Mendapatkan dana untuk pengadaan alat proses produ keu, makanan dan minuman berupa stand mixer dan blender.

\section{METODE PELAKSANAAN}

Tahapan pelaksanaan kegiatan pengabdian kepada masyarakat ini antara lain:

1. Melakukan riset untuk berdiskusi dan menyamakan presepsi dengan pengurus KUB "Forum Pemberdayaan Wanita Mandiri", dalam mencari solusi dan permasalahan yang ada, dengan prioritas utama adalah pelatihan dan pendampingan penyusunan pembukuan sederhana.
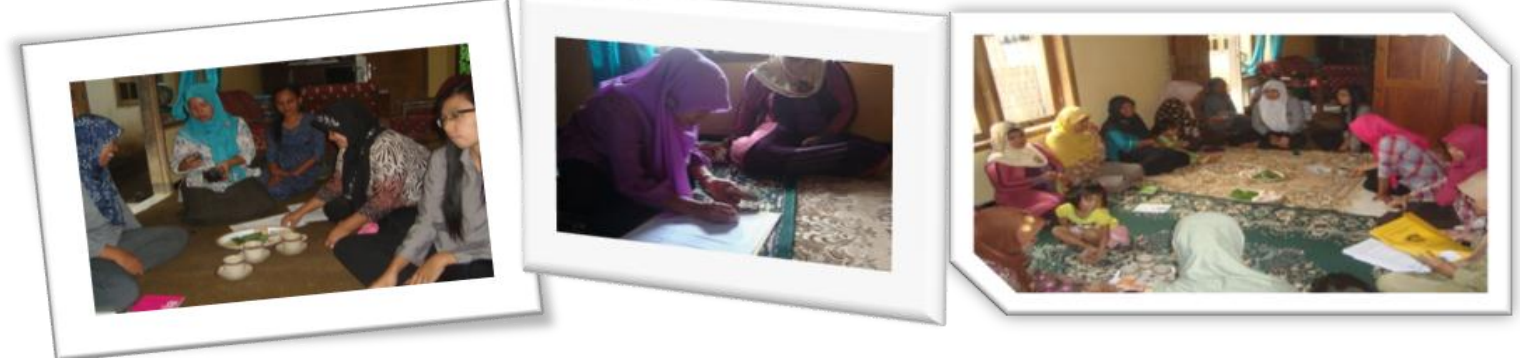

\section{Gambar 2. Diskusi dengan Pengurus KUB "Forum Pemberdayaan Wanita Mandiri"}

2. Memberikan pelatihan dan pendampingan penyusunan pembukuan sederahana, dengan langkah-langkahnya adalah:
(a) Pencatatan Transaksi ke dalam Persamaan Dasar Akuntansi
(b)Membuat Jurnal Umum/Transaksi
(c) Membuat Laporan Keuangan

3. Memberikan bantuan pembuatan beberapa buku pembukuan, anatara lain: buku besar, bertujuan untuk memberikan contoh dan memperlancar pelaksanaan pelatihan dan pendampingan pembuatan pembukuan bagi pengurus dan anggota KUB "Forum Pemberdayaan Wanita Mandiri".

4. Penyerahan bantuan dana untuk pengadaan alat produksi roti/cake dan kue kering, yaitu berupa pengaduk atau pencampur bahan/adonan roti/cake dan kue kering (stand mixer). Kegiatan bantuan ini bertujuan untuk kuantitas lebih optimal dan kualitas hasil yang lebih sempurna untuk produk roti/cake dan kue kering. Dan penambahan alat untuk melumatkan, mencincang halus, dan kasar makanan, sayuran dan buah-buahan (blender), agar hasil produk olahan lebih optimal (kuantitas produk meningkat). 
Pelaksanaan pengabdian pada masyarakat ini dibutuhkan partisipasi mitra agar program mencapai tujuan, antara lain:

1. Bersedia berdiskusi dan berpartisipasi aktif bersama tim pelaksana dalam pelaksanaan program pelatihan dan pendampingan pembuatan pembukuiasn sederhana.

2. Bersedia bekerjasama secara berkelanjutan untuk monitoring dan evaluasi yang secara periodik sampai kelompok mitra bisa mandiri dalam membuat dan menyusun pembukuan/laporan keuangan sederhana secara berkelanjutan.

\section{HASIL DAN PEMBAHASAN}

Mengadakan pelatihan dan pendampingan penyusunan pembukuan sederhana, serta pemberian dana untuk pengadaan beberapa buku besar dan pengadaan alat produksi roti/cake dan kue kering, yaitu berupa pengaduk atau pencampur bahan/adonan roti/cake dan kue kering (stand mixer). Tahapan pelaksanaan kegiatan pengabdian kepada masyarakat ini adalah:

\section{Tahap Pertama}

Pada awal ini melakukan kunjungan ke mitra Kelompok Usaha Bersama "Forum Pemberdayaan Wanita Mandiri" di Desa Tanggung Kecamatan Padang Kabupaten Lumajang, untuk berdiskusi membahas permasalahan mitra dan mencari solusi dengan prioritas utama adalah pelatihan dan pendampingan penyusunan pembukuan sederhana dan pengadaan buku-buku besar dan pengadaan alat produksi roti/cake dan kue kering, yaitu berupa pengaduk atau pencampur bahan/adonan roti/cake dan kue kering (stand mixer).

\section{Tahap Kedua}

Kegiatan riset ke lokasi pengabdian masyarkat ini dilakukan pada tahap kedua, dengan kegiatan koordinasi dengan pengurus dan beberapa perwakilan anggota KUB, yaitu:

(a) Membahas jadwal pelaksanaan kegiatan pelatihan penyusunan pembukuan sederhana.

(b) Membahas jadwal pelaksanaan kegiatan pendampingan penyusunan pembukuan sederhana.

(c) Membahas persiapan pelaksanaan kegiatan penyerahan salah satu alat produksi roti/cake dan kue kering, yaitu berupa pengaduk atau pencampur bahan/adonan roti/cake dan kue kering (stand mixer), dan penambahan alat untuk melumatkan, mencincang halus, dan kasar makanan, sayuran dan buah-buahan (blender).

(d) Membahas jadwal pelaksanaan monitoring dan evaluasi hasil pembuatan pembukuan sederhana dari peserta, yaitu pengurus dan beberapa anggota.

3. Tahap Ketiga

Pelaksanaan pelatihan dan pendampingan pembuatan pembukuan sederhana yang bertujuan agar bertujuan untuk agar pengurus dan anggota KUB "Forum Pemberdayaan Wanita Mandiri" bisa menyusun pembukuan sederhana dengan benar dan berkelanjutan. Pelatihan ini di awali dengan memberikan materi dengan contoh-contoh kasus tentang:

(1) Cara pencatatan transaksi ke dalam persamaan dasar akuntansi.

(2) Membuat jurnal umum/transaksi.

(3) Membuat buku besar (memindahkan jurnal umum/transaksi ke buku besar).

(4) Membuat laporan keuangan/pembukuan sederhana.

Pelaksanaan pelatihan dan pendampingan dengan jadwal yang telah ditetapkan, selama 2 dua) hari berturut-turut antara tanggal 17 Maret dan 18 Maret 2018. 

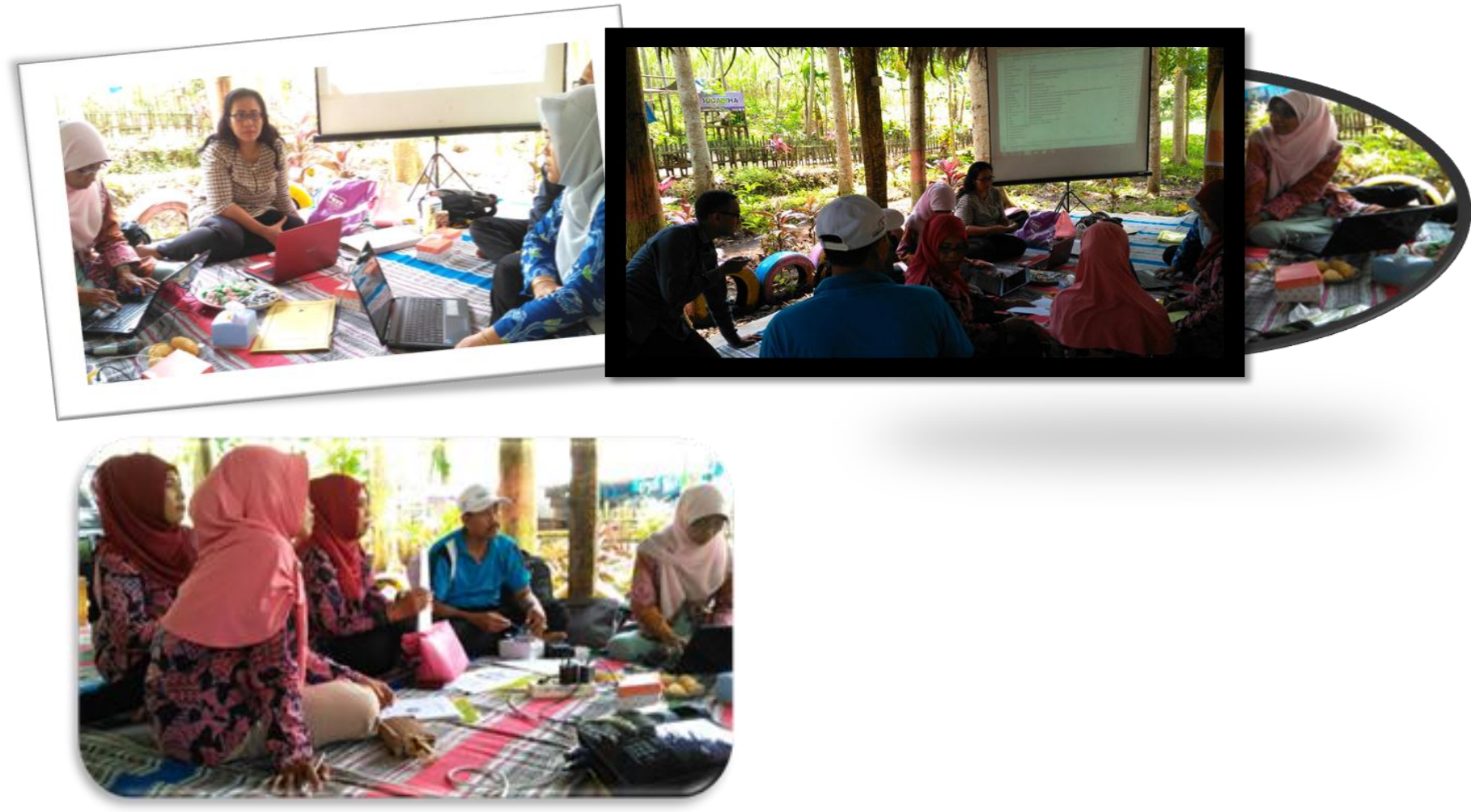

\section{Gambar 3. Pelaksanaan Kegiatan Pelatihan Pembuatan Pembukuan Sederhana}

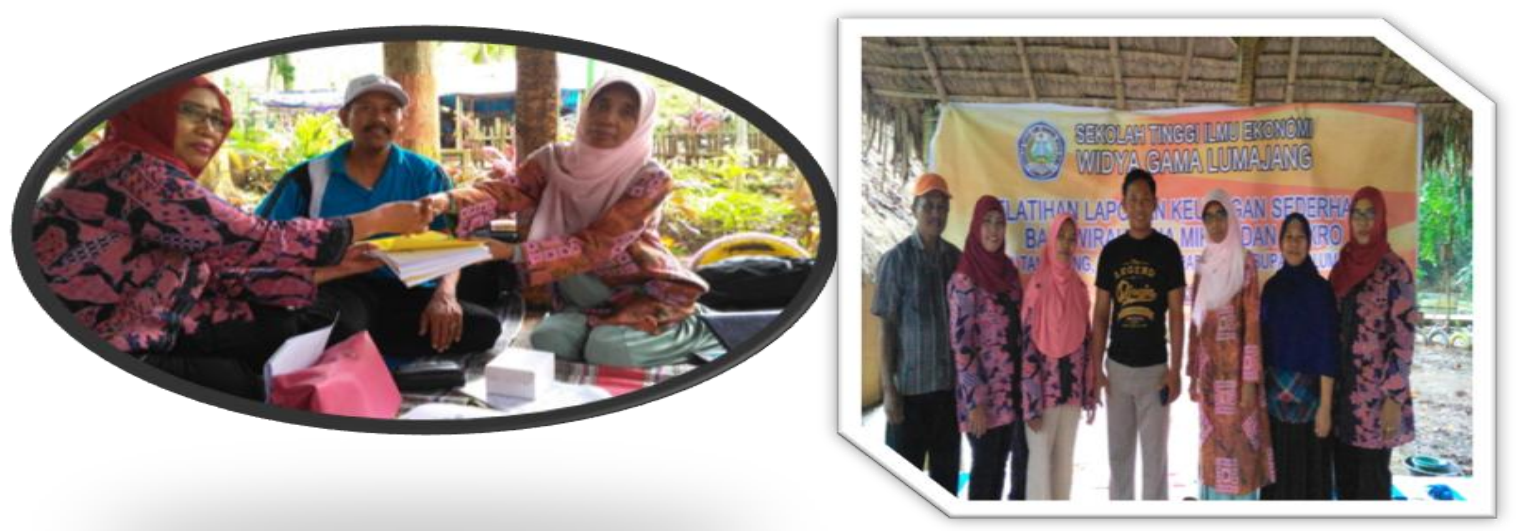

\section{Gambar 4. Penyerahan Buku-buku Pembukuan Sederhana}

4. Tahap Keempat

Pendampingan penyusunan dan pembuatan pembukuan sederhana, merupakan kegiatan praktek langsung oleh pengurus dan beberapa anggota KUB "Forum Pemberdayaan Wanita Mandiri". Kegiatan pendampingan di laksanakan di Sekretariatan KUB. Kegiatan pendampingan ini diharapkan dapat memberikan output, yaitu berupa kemampuan pengurus dan anggota untuk dapat membuat laporan keuangan atau pembukuan sederhana yang benar dan tepat serta berkelanjutan. Dengan pengelolaan keuangan sederhana yang benar dan tepat, akan memungkinkan KBU memperoleh data dan informasi yang tersusun secara sistematis atau teratur dan tertib, pengurus dapat memperhitungkan keuntungan yang diperoleh, 
mengetahui berapa tambahan modal yang dicapai, dan juga dapat mengetahui bagaimana keseimbangan hak dan kewajiban yang dimiliki. Sehingga setiap keputusan yang diambil oleh pengurus dalam mengembangkan usahanya akan didasarkan pada kondisi konkret keuangan yang dilaporkan secara tepat dan lengkap bukan hanya didasarkan pada asumsi semata.

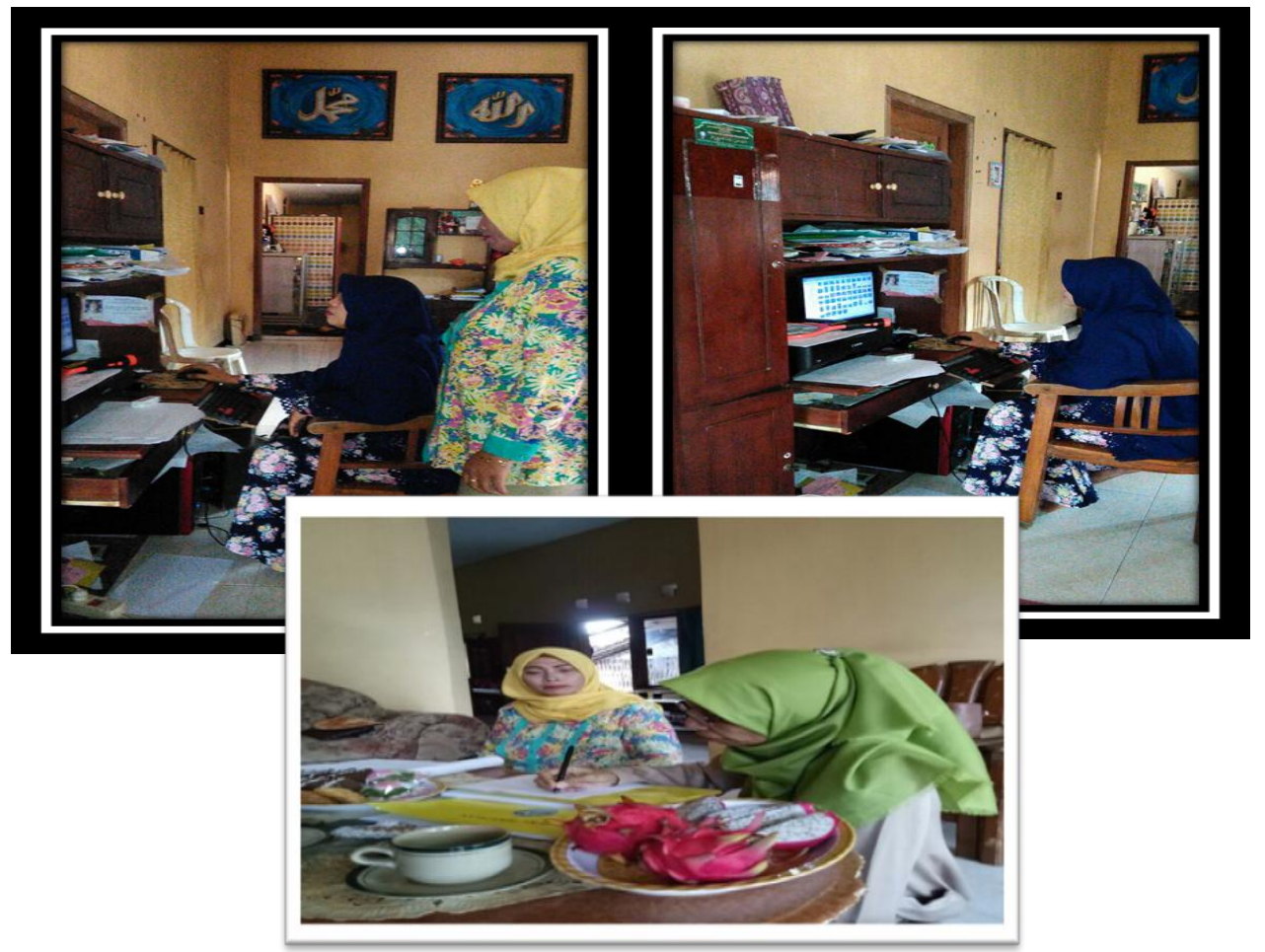

Gambar 5. Pendampingan Pembuatan Pembukuan Sederhana

\section{Penyerahan Bantuan Alat Prtoduksi}

Kegiatan penyerahan alat proses produksi kue yaitu berupa alat pencampur/pengaduk bahan kue, penambahan alat untuk melumatkan, mencincang halus, dan kasar makanan, sayuran dan buah-buahan (blender), agar hasil produk olahan lebih optimal. Bantuan ini dilaksanakan dengan tujuan untuk mendukung pengembangan usaha KUB "Forum Pemberdayaan Wanita Mandiri”.
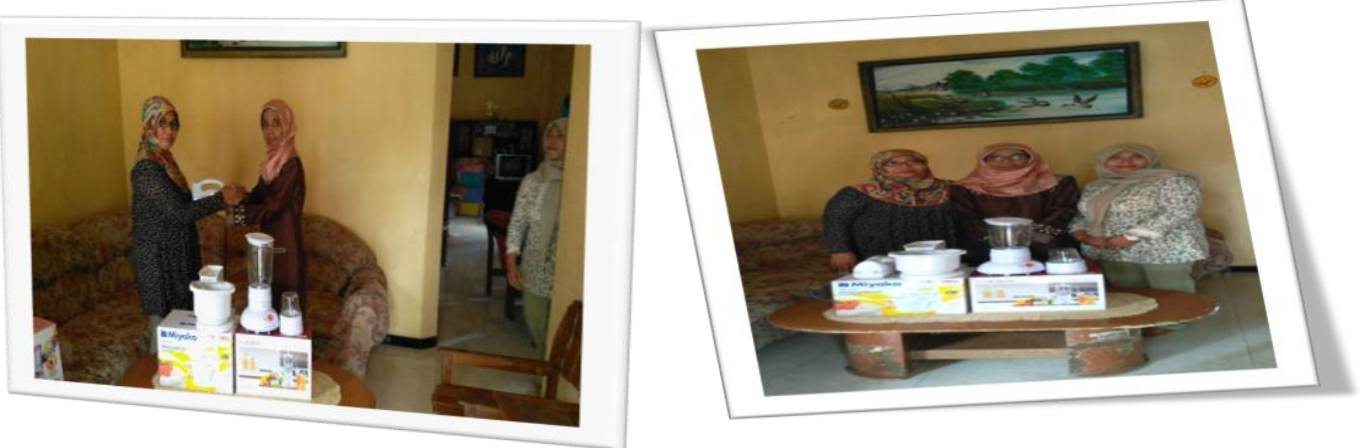

Gambar 6. Penyerahan Bantuan Alat Produksi 
Proses monitoring dan evaluasi secara periodik dilakukan dengan pendampingan untuk mendampingi pelaku usaha dalam memperbaiki pembukuan usahanya sampai dengan pengurus dan anggota mampu dalam membuat pembukuan yang tepat dan benar.

Tolak ukur dari keberhasilan pengabdian masayarakat pendampingan penyusunan pembukuan sederhana kepada KUB "Forum Pemberdayaan Wanita Mandiri" di Desa Tanggung, Kecamatan Padang, Kabupaten Lumajang ini adalah:

1. Peningkatan keterampilan pengurus dan anggota dalam membuat pembukuan sederhana yang benar dan tepat sertaberkelanjutan.

2. Mendapatkan dana untuk pembuatan beberapa buku catatan transaksi keuangan dan laporan keuangan sederhana.

3. Pengembangan usaha dan peningkatan pendapatan untuk semua anggota KBU.

4. Mendapatkan dana untuk alat proses produksi kue yaitu berupa alat pencampur/pengaduk bahan kue (stand mixer), dan penambahan alat untuk melumatkan, mencincang halus, dan kasar makanan, sayuran dan buah-buahan (blender), agar hasil produk olahan lebih optimal

Kegiatan pengabdian masyarakat ini dapat menghasilkan luaran yang diharapkan oleh pengurus dan anggota KUB "Forum Pemberdayaan Wanita Mandiri" di Desa Tanggung, Kecamatan Padang, Kabupaten Lumajang adalah antara lain :

1. Pengurus dan anggota terampil dalam membuat pembukuan sederhana yang benar dan tepat serta berkelanjutan

2. Pengembangan usaha baik dengan kunatitas dan kualitas produk/olahan makanan dan minuman serta kue, sehingga berdampak pada peningkatan pendapatan untuk semua anggota KBU.

\section{KESIMPULAN}

1. KUB "Forum Pemberdayaan Wanita Mandiri" dalam mengahadapi persaingan semakin meningkat dan ketat, memiliki kemauan yang kuat untuk tetap eksis dan mempunyai cita-cita untuk mengembangkan usahanya dengan pengembangan produk (menambah jenis produk ) yang sudah dihasilkan dan peningkatan kualitas produk.

2. Kegiatan pengabdian kepada masyarakat ini dilaksanakan bisa memberikan salah satu solusi KBU dapat mengembangan dan meningkatkan kualitas produknya. Agar usaha tetap berkelanjutan, mengembangkan usaha kelompoknya, untuk meningkatkan daya saing di pasar lokal dan di pasar regional, serta lebih bertambah terserapnya tenaga kerja dari Kelompok Usaha Bersama.

3. Target tercapainya kegiatan pengabdian kepada masyarakat ini adalah: :

(a) peningkatan keterampilan pengurus dan anggota dalam membuat pembukuan sederhana yang benar dan tepat serta berkelanjutan.

(b) mendapatkan dana untuk pembuatan beberapa buku catatan transaksi keuangan dan laporan keuangan sederhana.

(c) pengembangan usaha dan peningkatan pendapatan untuk semua anggota KBU.

(d) mendapatkan dana untuk pengadaan alat proses produksi kue yaitu berupa alat stand mixer dan blender.

4. Luaran yang dihasilkan dalam pengabdian ini dan merupakan harapan dari mitra adalah:

(a) pengurus dan anggota terampil dalam membuat pembukuan sederhana yang benar dan tepat serta berkelanjutan,

(b) pengembangan usaha dan peningkatan pendapatan untuk semua anggota KBU.

\section{Saran}

1. Perlu adanya kemauan dan semangat dari pengurus dan anggota KUB untuk meningkatkan daya saing produk industry makanan dan minuman olahan serta aneka kue, 
yaitu dengan penngkatan kemampuan dan ketrampilan pengurus dan anggota KUB antara lain inovatif, kratifitas pengolahan makanan, minuman, dan kue. Untuk tercapainya hal tersebut pengurus dan anggota harus selalu mengikuti pelatihan-pelatihan di bidang wirausaha dan manajemen (bidang pemasaran dan produksi).

2. Pendampingan yang berkelanjutan kepada pengurus dan anggota KBU sangat diperlukan dari STIE Widya Gama Lumajang dalam bidang manajemen lainnya, agar KBU" "Forum Pemberdayaan Wanita Mandiri" di Desa Tanggung, Kecamatan Padang, Kabupaten Lumajang, memenuhi permintaan pasar, dapat mengembangkan usaha kelompoknya, dapat meningkatkan daya saing di pasar lokal dan di pasar regional, serta lebih bertambah terserapnya tenaga kerja dari kelompok untuk kegiatan menghasilan pengembangan produk, serta meningkatnya kualitas produknya. Hal tersebut akan berpengaruh meningkatkan nilai pendapatan. Secara tidak langsung juga berpenterhadap taraf hidup para anggotanya.

3. Masih membutuhkan pendanaan untuk pengadaan beberapa alat produksi yang lebih modern dan canggih untuk: Meningkatkan diversifikasi dan inovasi produk, meningkatkan produktivitas, meningkatkan kapasitas produksi dan mengembangkan efektifitas usaha.

\section{DAFTARA PUSTAKA}

Departemen Koperasi, Beberapa Model Pengembangan Usaha Kecil. (http://tatangfh.wordpress.com.)

Kebijakan Umum Pembinaan dan Pengembangan KUKM. (http://tatangfh.wordpress.com.)

Rifai,Melly Sri Sulastri. Ekonomi Keluarga. Bandung: TKTP Bandung. 2010

Surachman, Sumawihardja. 2003. Mengembangkan Keunggulan Bersaing Usaha Kecil dan Menengah untuk Mencapai Posisi Pasar yang Kuat dan Berkelanjutan dalam Era Global. (https://kartawan.files.wordpress.com) 